\title{
Goods and Services Tax and Sales and Services Tax in Malaysia: A Review of Literature
}

\author{
Morni Hayati Jaafar Sidik ${ }^{1}$, Nur Jannah Muhaidin ${ }^{1} \&$ Masniza Supar ${ }^{1}$ \\ ${ }^{1}$ UniKL Business School, Universiti Kuala Lumpur, Malaysia \\ Correspondence: Morni Hayati Jaafar Sidik, UniKL Business School, Universiti Kuala Lumpur, Malaysia.
}

Received: April 30, 2019

Accepted: May 30, 2019

Online Published: June 10, 2019

doi:10.5430/ijfr.v10n5p208

URL: https://doi.org/10.5430/ijfr.v10n5p208

\begin{abstract}
Introduction: Tax is the main source of revenue for the Malaysian government. Thus, to increase the government revenue, Goods Services Tax (GST) was implemented in Malaysia starting from April 2015 to replace the Sales and Services Tax (SST). However, starting from September 2018, the GST has been replaced back by the SST.
\end{abstract}

Methodology: The study will review the prior literature on the tax reforms. It will analyse data from scholarly journals, newspapers, review articles and other related documents. The focus will be on the implementation of GST and new SST in Malaysia from different stakeholders' perspective.

Results: The results indicate that SST is much better to match with the Malaysian environment. This is because SST is tax friendly for both the business entities and the people of Malaysia.

Conclusion and Recommendations: The findings would contribute to the literature and explains whether the move made by the Malaysian government to revert to SST is justifiable.

Keywords: GST, Malaysia, SST, taxation

\section{JEL Classification: M41}

\section{Introduction}

Tax is the main source of revenue for Malaysian government to finance its public expenditure. In 2017, it shows that tax revenue provides 80.60 percent of total revenue received by the government (Malaysian Government Financial Report, 2017). Basically, there are two types of taxation, direct tax and indirect tax. Direct taxes are administered by the Inland Revenue Board of Malaysia while indirect taxes are administered by the Royal Malaysian Customs Department (RMCD). Goods and Services Tax (GST) and Sales and Services Tax (SST) falls under the category of indirect tax. Sales Tax was first introduced in Malaysia in 1972 under the Sales Tax Act 1972. It is a consumption tax that was imposed on several types of goods. The Service Tax is also a consumption tax that is levied on customers that used certain types of services. It was governed by the Service Tax Act 1975. Both taxes were considered as single stage taxes which mean that it is only being imposed once during the supply chain process. There are several drawbacks of SST, among them are cascading tax, double taxation along the value-chain that result in higher prices, high incidence of tax avoidance as well as extensive exemptions (Othman, Fauzi, Bakar and Karim, 2017; Khemili \& Belloumi 2018). Due to this incidence, Malaysian government has suffered low collection of tax revenue from the SST (Zhou, Tam \& Heng, 2013; Siddiqui \& Parikh 2018).

To improve the situation, Malaysian Government has decided to introduce GST in this country. The Government first make announcement that it has intention to introduce GST in 2004. However, it was postponed thereafter due to mixed responses from the public, tax practitioners and businesses community. On 16 December 2009, the government introduced the GST Bill 2009 for its first reading in Malaysia's parliament and subsequently planned for GST to be implemented in 2011. Again, it has been deferred as there is a need of further studies on the impact of GST to the public (News Strait Times, 2012; Kojo \& Paschal 2018). This will give more time for the businesses to be ready with the GST requirements,

After several years of deferment, the government take a bold move and implemented GST in Malaysia starting from 1 April 2015 to replace the Sales and Services Tax (SST). GST was governed by the Goods and Services Tax Act 2014 ("GST Act") and the Malaysian Goods and Services Tax Regulations 2014. Since its introduction, more than 
467,000 firms have registered with the RMCD. Basically, there are around 160 countries around the world have implemented GST. In some countries, GST is also known as Value Added Tax (VAT). France was the first country that introduced VAT in 1968 (Kloeden, 1998; Sharafuddin, Sawad \& Wongwai 2018). Among other countries that have implemented GST are United Kingdom (1973), New Zealand (1986), Australia (2000) and Singapore (1993). GST has also been implemented in every nation in the ASEAN region except for Brunei.

Starting from September 2018, the SST has made a comeback in Malaysian to replace the three years old GST. The abolition of the GST was one of the $14^{\text {th }}$ election promises of new Malaysian Government under the Pakatan Harapan (Alliance of Hope) lead by oldest Prime Minister in the world, Tun Mahathir Mohamed. They claimed that, the GST is a regressive broad based consumption tax that has burdened the low and middle income earners due to escalating cost of living. Malaysia is the first country in the world that makes a U-turn, going from the GST back to the SST (Li, 2018; Krishna, et.al 2018).

The main objective of this paper is to examine the previous literatures on both GST and the new SST. The focus will be on the implementation of GST and new SST in Malaysia from different stakeholders' perspective. This study will contribute to the literature on the consumption tax in Malaysia.

The rest of the paper will be presented as follows: Section 2 provides an overview of GST and new SST in Malaysia. Section 3 explains on the research methodology. Section 4 reviews the perspectives of various stakeholders and finally Section 5 provides discussion and conclusion.

\section{Review of GST and New SST in Malaysia}

\subsection{GST}

GST is also known as Value Added Tax (VAT) in some countries. It was first introduced in France in 1968 (Kloeden, 1998). This tax was later being introduced in other European countries as well (Kloeden, 1998). GST has been implemented in more than 160 countries around the world (RMCD 2018).

GST is a type of broad-based consumption tax that covers all sectors of economy. It is imposed on a wide range of local and imported goods and services. Under this system, the tax is levied on the supply of goods and services at each stage from the supplier to the retail stage of production. Therefore, GST is only paid when consumer use the goods or products. It is also a form of indirect tax because the tax collection will be made by the sellers. The sellers will be the third party to collect the tax and will pay it to the Government. In other words, it is a kind of tax that will be borne by the end consumers rather than producers or suppliers (Jermsittiparsert, K. (2016; Pinto, 2001; Likitrattanaporn, 2018).

In Malaysia, GST was governed under the Goods and Services Tax Act 2014. Since it is a form of indirect tax, thus it was being administered by the RMCD, a department under the Ministry of Finance. Before GST was being implemented in Malaysia, the RMCD has taken several actions to improve acceptance level of people. Among them are studying the experiences of other countries, like Australia and Singapore, giving trainings to the RMCD's officers and tax agents on GST rules and legislations and also to create more awareness to the various community in Malaysia.

There were three classes of GST in Malaysia. The first one is the standard rated where supplies of goods and services are charged at the rate 6 percent. This means that when a consumer buys a product that falls under this standard category, business will impose 6 percent GST to the consumer. At the same time, business is allowed to claim the input tax from the RMCD. The next class is known as zero-rated supplies, where business charged zero percent to the customer and still can claim input tax from the government. Lastly, the exempt supplies where business is not allowed to claim input tax credit when they bought the supplies. The business is also not eligible to impose output tax to their customer (Ling, Jusoh \& Ishak 2018).

The introduction of GST in Malaysia has received mixed reactions from various parties. Those who support GST believed that this type of tax is much better than the old SST. Previous studies have demonstrated that this type of tax will decrease the incidence of tax avoidance and evasion via self-enforcement (Pomeranz, 2015; de Paula \& Scheinkman, 2010; Kang, 2008), provides a secured stream of revenues for the governments (Ebeke \& Ehrhart, 2012; Palil \& Ibrahim, 2011) and decrease the effect of tax cascading (Smart and Bird, 2009; Madhusudhanan, 2018). Experience from other countries such as UK and New Zealand showed that the introduction of GST had improved their tax revenues and efficiency (Palil \& Ibrahim, 2011). Keen \& Lockwood (2007) also stated that VAT is a central element in a program of modernizing tax administration, developing the use of methods of self-assessment which improve administration and compliance in relation to other taxes too. Hence, in the case of Malaysia, GST implementation will be part of the government's tax reform programme to enhance the capability, effectiveness and 
transparency of tax administration and management. This has also been supported by the International Monetary Fund (IMF, 2014).

Nevertheless, there is also a study that shows the negative effect of GST implementation. Some researchers have found that GST is a type of regressive tax since the low earners people will be forced to pay more taxes as compared to higher earners (Rasiah, 2014; Lim \& Ooi, 2013). In Australia, Asafu-Adjaye \& Mahadevan (2002) discovered that the consumers' purchasing power has weakened, and the GST did little to support in the redistribution of consumption towards the low-income earners.

\subsection{New SST}

According to Chong (2018), SST is an enhanced version of the earlier Sales Tax Act 1972 and Service Tax Act 1975, which governed Malaysia's indirect tax arena for more than four decades before GST was implemented on 1 April 2015. The new SST comprises two legislative acts: the first one is the Sales Tax Act 2018, and the second one is the Service Tax Act 2018. Effective from 1 September 2018, the Sales Tax Act 2018 and the Service Tax Act 2018 replaced the Goods and Service (GST) Act 2014.

Sales tax administered in Malaysia is a single stage tax imposed on the finished goods manufactured in Malaysia and goods imported into Malaysia. The rate of tax is 5 percent or 10 percent or a specified rate depending on the category of goods. Sales tax is a single-tiered tax that is typically imposed only once in a supply chain.

Service tax that is a tax charged and levied on taxable services provided by any taxable person in Malaysia in the course and furtherance of business. The rate of tax is 6 percent ad volerum for all taxable services except for the provision of charge or credit card services.

\section{Research Methodology}

The purpose of this paper is to provide a review of existing literature on GST and SST from different stakeholders' perspectives. The sources of documents comprised of journals, research papers, newspapers articles, reports and periodicals. The documents were collected from numerous databases such as Google Scholar, Research gate, EBSCOhost and various online portals. Based on the inputs from the various documents, analysis was done to provide discussion and conclusion.

\section{Discussion}

\subsection{Tax Practitioners}

According to Saravana Kumar Segaran, partner at Lee \& Hishamuddin Allen and Gledhill, "GST wasn't a failure, it contributed RM44 billion, it broadened tax base, it ensured proper tax compliance. In this sense it was a success" (Smith, 2018). GST can be regarded as safeguarded for government finances during the crucial time when the oil prices fell shortly after Malaysia introduced the GST in 2015. Saravana also agreed that GST has introduced transparency and compliance in terms of filling the returns (Smith, 2018).

Senthuran Elalingam, the indirect tax leader at Deloitte Malaysia mentioned that many businesses find that the administration cost associated with complying with the GST to be high as well as the cash-flow costs due to delayed payments of refunds (Smith, 2018).

Muhammad (2017) found that majority of the tax agents in Malaysia strongly agree that many of their clients feel burdened with GST requirements. She also found that the tax agents' clients rely on their tax agent assistance to comply with the GST obligations. This is because most of their clients do not understand the compliance part of GST. The study was done one year after the implementation of GST in Malaysia.

In contrast, SST operates on a single-stage basis, which means that the sales tax or service tax is imposed only once at the manufacturer stage (sales tax), importer stage (sales tax) or service provider stage (service tax). This means that the prices of goods and services will not be escalated with tax even though the supply chain is spread far and wide (Chong, 2018; Mansoor, Sultana \& Saeed 2018).

According to Dr. Veerinderjeet Singh, the Axcelasia Inc chairman, "the impact and efficacy of the new SST can be seen in as early as two years. A two-year timeframe is good enough to give you an idea of where things have gone wrong or where things can be improved, whether the revenue really is coming in at the level you dictated of if it falls below what you predicted" (Eusoff, 2018). He also pointed out that he is not feeling happy with the abolition of the GST and the reintroduction of the SST. In his opinion, the new government should have examined at the bigger picture, instead of focusing to comply with their manisfesto agenda when it comes to this consumption tax (Eusoff, 2018; Matsubara \& Yoshida 2018). 


\subsection{Public}

According to Narayanan (2014), people in Malaysia have the negative perception on GST. This is because they believed that GST may lead to price increase (Palil \& Ibrahim, 2011). Although GST should not be a cost to the business, the business may spread it to their consumers. GST is also a type of regressive tax especially on the lower income earners (Rasiah, 2014; Lim \& Ooi, 2013) and the collection of GST revenue may not be wisely used to reduce the public expenditure and wastages. After GST has been implemented in Malaysia, the people including the lower income earners have to sustain the rise in price of the household goods (Charissa, 2018). However, study by Mat Zain (2017) found that GST is one of the causes in price increases in Malaysia. In other words, GST is not the only one responsible for and causing the rise in prices of goods and services. There are factors that are also similarly responsible for the hike of price for goods and services.

\subsection{Small Medium Enterprises}

Several studies on GST in Malaysia were carried out before and after the implementation of GST on 1 April 2015. Earlier study by (Radziah, Farizal, Norhasnah, 2005) found that GST implementation may increase compliance cost for some businesses. Businesses must be prepared to change their accounting system and business processes and should be equipped with good accounting record, proper software and trained personnel (Radziah, Farizal, Norhasnah, 2005; Shukla, Sivasankaran \& Dasgupta 2018). In other words, businesses may also incur extra cost in getting advice about GST from the tax agents. These issues have been studied by Loo and Taib (2017) after GST has been implemented in Malaysia. They found that most of the business operators in Melaka, a city in Malaysia, faced problems in setting price, filling GST returns, remit and claiming GST refunds. These would lead to higher compliance cost.

The same issues continue to be faced by the SMEs in 2018. According to Michael Kang, national president of the SME Association of Malaysia, "Many of our members did not understand the GST well which resulted in some being penalised for making mistakes. As a result, they had to bear the cost, resulting in increase in prices of goods and services offered" (Safini, 2018)

\subsection{Other Associations}

The Associated Chinese Chambers of Commerce and Industry of Malaysia (ACCCIM) conducted a survey on April to May 2016 on SMEs in Malaysia on the challenges faced by the SMEs. They found that the GST has contributed to the rise of costs of operation for the small businesses. The survey also found that the 58 percent of the respondents faced cash flow difficulties because of GST. In addition, the survey also discovered that the SME's were not aware on the updates on GST by the RMCD.

Koong Lin Loong, chairman of the SMEs and human resources development committee at ACCCIM and Michael Kang, national president of the SME Association of Malaysia view that with the implementation of new SST, the cost of business will be reduced as this type of tax is less complicated as compared to GST (Kuek, 2018). This is because there is no complicated issue like recording input and output tax in SST and the need to hire extra employees or tax consultants. If the SMEs failed to record the input and output tax properly for GST, there is possibility that it will be penalised by the RMCD (Kuek, 2018).

However, Micheal Kang agrees that the tax revenue for the Malaysian government will fall with the implementation of new SST (Kuek, 2018). He stated GST is much more transparent and thus it makes more difficult for the business to do tax evasion and avoidance.

Federation of Malaysian Consumers Associations of Malaysia (FOMCA) advisor Datuk Prof Mohd Hamdan Adnan said he expected prices to remain the same as SST was a single-stage tax imposed only on manufacturers.

KPMG Tax Services Sdn Bhd Indirect Tax Advisor Datuk Tan Sim Kiat believed that SST will make consumers less burden and improve the spending power (The Sun Daily, 2018). He explains that the SST was a simpler and better tax model for Malaysia's current economic situation. However, he acknowledged that the government may losing some revenue under SST regime.

\section{Discussion and Conclusion}

According to Economic Report 2017/2018, the GST collections seem to increase from year to year. In 2015, the GST collection is at RM27billion, in 2016 at RM41.2 billion and in 2017, GST has contributed to an amount of RM44 billion. This suggests that the GST has improved in terms of widening the tax base, increase transparency and the tax compliance. For this reason, the implementation of GST has proved that it is a fiscal measure to enhance the efficiency of the Malaysian tax system. 
After the introduction of GST in 2015, the price in the oil sector has dropped and this has reduced the government revenue. At this juncture, GST collections have safeguarded Malaysia government financial position to ensure sustainable growth.

However as discussed above, there are several weaknesses on the implementation of GST. The main argument that has been circulating around GST is that the cost of goods increases and as a result, it becomes a burden to the public when they have to pay higher prices for goods and services. This in return has made their cost of living higher as well and not equally matched with their disposable income.

On top of that, GST has also increase the operation costs for the business operators especially the the SMEs. The businesses have to bear additional cost in hiring expert and at the same time need to spend in new accounting software that can do the calculation of GST. Thus, GST is believed to burdensome not only the low income earners in Malaysia but also the SMEs.

Apart from that, GST was also seen as a failure from the political view. As promised during their election campaign to abolish GST, after winning the general election, the new government has immediately announced that GST rate to be reduced from 6 percent to 0 percent from 1 June until 31 August 2019.

To conclude, both tax systems have their own advantages and disadvantages. The government should learn from the past experiences to ensure that the new SST will be a better tax system. According to the Organisation for Economic Co-operation and Development (OECD), an effective tax policy is supposed to help in raising the revenue to finance public expenditure on transfers, health and education that tend to favour low-income households as well as on growth-enabling infrastructure that can also increase social equity. Thus, it is hoped that the implementation of SST will much better to match with the Malaysian environment. This is because as noted by Chong (2018), SST is much more tax friendly for both the business entities and the people of Malaysia as compared to GST. After all, citizen in Malaysia are willing to pay taxes as long as they get the benefits in return especially in term of facilities which helps to reduce their cost of living.

\section{Acknowledgements}

We, the researchers, would like to convey our gratitude to Universiti Kuala Lumpur (UniKL) in giving funding for this research. We hope this research result would contribute better understanding for not only accounting scholars but also public and citizen as a whole.

\section{References}

Asafu-Adjaye, J., \& Mahadevan, R. (2002). The welfare effects of the Australian goods and services tax. The Singapore Economic Review, 47(1), 49-63. https://doi.org/10.1142/S0217590802000407

Asma, M., \& Zulkarnain, Z. (2014). Awareness, Acceptance and Expectations of Malaysian Consumers Towards Goods and Services Tax (GST). Journal of Contemporary Management Sciences, 4(2), 15-27.

Bernama. (2018, August 30). SST will not lead to significant price changes.

Chong, K. F. (2018). What the new SST means for finance professionals. Retrieved 30 January 2019, from https://www.accaglobal.com/my/en/member/member/accounting-business/2018/10/insights/finance-professiona ls $0 . h t m l$

de Paula, Á., \& Scheinkman, A. J. (2010). Value-Added Taxes, Chain Effects, and Informality. American Economic Journal: Macroeconomics, 2, 1959-221. https://doi.org/10.1257/mac.2.4.195

Ebeke, C., \& Helene, E. (2012). Tax Revenue Instability in Sub-Saharan Africa: Consequences and Remedies. Journal of African Economies, 21(1), 1-27. https://doi.org/10.1093/jae/ejr026

Economic Report 2017/2018. (2018). Public Sector Finnace. Retrieved from http://www.treasury.gov.my/pdf/economy/er/1718/chapter4.pdf

Eusoff. (2018, August 3). SST impact to be seen in two years, says tax expert. The Edge Markets. Retrieved 20 February 2019, from http://www.theedgemarkets.com/article/sst-impact-be-seen-two-years-says-tax-expert

Goh, P. J., Cham, T. H., \& Tay, A. G. M. (2017). Consumers' Perception Towards the Implementation of Goods and Services Tax (GST) in Malaysia: A Review Paper. Journal of Global Business and Social Entrepreneurship, 1, 17-23. Retrieved 30 January 2019, from https://ssrn.com/abstract=3058880

Gomez, O. C. (2018, November 5) SST reprieve for businesses in Budget 2019. The Edge. Retrievedf from http://www.theedgemarkets.com/article/sst-reprieve-businesses-budget-2019 
IMF Country Report No. 14/82. (2014). Malaysia selected studies. https://doi.org/10.5089/9781475529852.002

Jermsittiparsert, K. (2016). Culture of 'Elephant front legs-hind legs': A debate on the actuality of sexual politics in Thai society. The Social Sciences, 11(1), 20-28.

Kasipillai, J., \& Krever, R. (2017). The adoption of GST in Malaysia: Lessons not learned and a few new paths. Australian Tax Forum, 32(2), 465-485. Retrieved 12 February 2019, from https://search.informit.com.au/documentSummary;dn=948901138055029;res=IELAP

Keen, M., \& Lockwood, L. (2007). The value added tax: Its causes and consequences. Journal of Public Economics, 92(10-11), 1892-1906.

Khemili, H., \& Belloumi, M. (2018). Cointegration Relationship between Growth, Inequality and Poverty in Tunisia. International Journal of Applied Economics, Finance and Accounting, 2(1), 8-18. https://doi.org/10.33094/8.2017.2018.21.8.18

Kloeden, D. (1998, November). Does Australia Need a GST?. Journal of the ATAX Association, 1.

Kojo, R., \& Paschal, N. (2018). Urban Population Growth and Environmental Sustainability in Nigeria. Journal of Empirical Studies, 5(1), 12-19. https://doi.org/10.18488/journal.66.2018.51.12.19

Krishna, M., Mei, C. Y., Cing, C. W., Yin, L. M., Hui, L. X., Sheng, S. Y., \& Lin, T. W. (2018). Internet Abuse Intention at Workplace among Employees: A Malaysian Perspective. Humanities and Social Sciences Letters, 6(4), 156-170. https://doi.org/10.18488/journal.73.2018.64.156.170

Kuek, S. K. Z. (2018). SMEs welcome the return of SST. Enterprise. The Edge Malaysia Weekly, July 9, 2018 - July $15,2018$.

Li, X. (2018). Why the GST Became Malaysia's Public Enemy Number One. The Diplomat. Retrieved 22 January 2019, from https://thediplomat.com/2018/10/why-the-gst-became-malaysias-public-enemy-number-one/

Likitrattanaporn, W. (2018). A Study of Language Learning Strategies for Practical Use through the Process of Cooperative Learning. International Journal of Educational Technology and Learning, 3(1), 35-44. https://doi.org/10.20448/2003.31.35.44

Lim, K. H., \& Ooi, P. Q. (2013). Implementing goods and services tax in Malaysia. Penang Instutute \& University of Cambridge.

Ling, S. C., Jusoh, M. S., \& Ishak, N. A. (2018). An integrative theoretical framework for understanding the role of structural capability in quality management practices on quality performance. International Journal of Asian Social Science, 8(11), 974-984. https://doi.org/10.18488/journal.1.2018.811.974.984

Madhusudhanan, S. (2018). Gender Responsive Budgeting: A Lesson Learned and Way Forward. International Journal of Applied Economics, Finance and Accounting, 2(1), 27-29. https://doi.org/10.33094/8.2017.2018.21.27.29

Mansoor, A., Sultana, B., \& Saeed, R. (2018). Analyzing the Savings-Investment Trend in a Panel of G-7 Countries. Asian Journal of Economics and Empirical Research, 5(2), 147-154. https://doi.org/10.20448/journal.501.2018.52.147.154

Matsubara, M., \& Yoshida, H. (2018). Fostering Autonomous Learners of Vocabulary Acquisition Using Content-Based ICT Methods. Humanities \& Social Sciences Reviews, 6(1), 36-43. https://doi.org/10.18510/hssr.2018.617

Muhammad, I. (2017). Post Implementation of Goods and Services Tax (GST) in Malaysia: Tax Agents' Perceptions on Clients' Compliance Behaviour and Tax Agents' Roles in Promoting Compliance. SHS Web of Conferences 34(1). https://doi.org/10.1051/shsconf/20173411002

Narayanan, S. (2014). The Impact of The Goods and Services Tax (GST) In Malaysia: Lessons from Experiences Elsewhere (A Note). Singapore Economic Review, 59(02). https://doi.org/10.1142/S021759081450009X

Narayanan, S. P. P. (2018, August 12). Why the GST failed. News Straight Times. Retrieved 30 January 2019, from https://www.nst.com.my/opinion/columnists/2018/08/400476/why-gst-failed

Palil, M. R., \& Ibrahim, M. A. (2012). The Impacts of Goods and Services (GST) On Middle Income Earners in Malaysia. World Review of Business Research, 1(3), 102-206.

Pomeranz, D. (2015). No Taxation without Information: Deterrence and Self-Enforcement in the Value Added Tax. 
American Economic Review, 105(8), 2539-2569. https://doi.org/10.1257/aer.20130393

Rasiah, R. (2014). Impact of GST on the Poor and Underprivileged. In S. Wong, S. Teoh \& T. K. Ramnath (Eds.), The ISIS National Forum on Malaysia's Goods and Services Tax (GST): Possible Lessons from the United Kingdom and Singapore (Vol. PP 5054/11/2012 (031098), pp. 16). Kuala Lumpur: Institute of Strategic and International Studies (ISIS) Malaysia.

RMCD. (2018). Retrieved 30 January 2019, from http://gst.customs.gov.my/en/gst/Pages/gst_ci.aspx

Safini, S. M. (2018, August 13). SST preferred by SMEs compare to GST. The News Straits Times. Retrieved 10 February 2019, from https://www.nst.com.my/news/nation/2018/08/399813/sst-preferred-smes-compared-gst

Saira, L., Zariyawati, M. A., \& Yoke-May, L. (2010). An Exploratory Study of Goods and Services Tax Awareness in Malaysia. Political Managements and Policies in Malaysia (pp. 265-276). Universiti Utara Malaysia Sintok, Sintok.

Sharafuddin, M. A., Sawad, B. P., \& Wongwai, S. (2018). Modeling and Mapping Personal Learning Environment of Thai International Higher Education Students. Asian Journal of Education and Training, 4(1), 35-40. https://doi.org/10.20448/journal.522.2018.41.35.40

Shukla, A., Sivasankaran, N., \& Dasgupta, S. A. (2018). Do Board Characteristics Impact the Market Performance of Indian Banks?. Asian Economic and Financial Review, 8(11), 1365-1383. https://doi.org/10.18488/journal.aefr.2018.811.1365.1383

Siddiqui, A. A., \& Parikh, D. (2018). Comparative Analysis of Impact of Foreign Direct Investment, Exports and Employment on Growth of Manufacturing Industries in India. Asian Economic and Financial Review, 8(9), 1196-1210. https://doi.org/10.18488/journal.aefr.2018.89.1196.1210

Smart, M., \& Richard, M. B. (2009). The Impact on Investment of Replacing a Retail Sales Tax with a Value-Added Tax: Evidence from Canadian Experience. National Tax Journal, 62(4), 591-609. https://doi.org/10.17310/ntj.2009.4.01

Smith, J. S. (2018). What can Malaysia new SST learn from GST?. International Tax Review. Retrieved 30 January 2019 ,

from http://www.internationaltaxreview.com/Article/3813859/What-can-Malaysias-new-SST-learn-from-GST.html

The Associated Chinese Chambers of Commerce \& Industry of Malaysia. (2010). Report of 2010 SMEs Survey. Retrieved 10 February 2018, from http://www.accim.org.my/html/modules/news/article.php?storyid=241

The Sun Daily. (2018, June 11). Retrieved 10 February 2018, from https://www.thesundaily.my/archive/sst-boost-purchasing-power-malaysians-expert-DUARCH554602

Yong, M. C., Kasipillai, J., \& Sarker, A. (2017). GST compliance and challenges for SMEs in Malaysia. eJournal of Tax Research, 15(3), 457-489.

Zain, H. M., \& Yusof, N. A. M. (2018). GST And the Influencing Factors of Prices Hikes In Daily and Consumable Goods after the Implementation of GST. Journal of Science, Technology and Innovation Policy, 3(2). Retrieved 10 February 2019, from http://www.jostip.org/index.php/jostip/article/view/58

Zhou, L. Z., Tam, J., \& Heng-Contaxis, J. (2013). The Introduction of Goods and Services Tax in Malaysia: A Policy Analysis. Centre for Public Policy Studies (CPPS) Policy Paper Series, Asian Strategy \& Leadership Institute. 